\title{
МЕТАФОРИЧНІ МОДЕЛІ ГРОМАДЯНСЬКОЇ І НАЦІОНАЛЬНОЇ САМОІДЕНТИФІКАЦІЇ МОЛОДІ
}

Обгрунтовано припущення щодо зумовленості громадянської і національної самоідентифікації метафорами, які обирає молодь, характеризуючи різні аспекти взаємодії з державою, владою, спільнотою тощо. Показано, що типові метафоричні практики не просто відображають реальні комунікативні процеси, а й активно спрямовують їхній розвиток, відіграють важливу роль не лише в конструюванні картини світу особистості, а й у позиціюванні щодо окремих ii систем, зокрема таких, як “людина - держава”, “людина - спільнота”, “людина нація". Представлено результати емпіричного дослідження метафоричних моделей громадянської і національної самоідентифікації молоді. За результатами факторного аналізу встановлено, що самоідентифікування студентської молоді вибудовується з метафори, базовим смислом якої $є$ уявлення про цінність держави. Більше ніж половина респондентів вибудовують ідентичність 3 моделі обміну (“держава цінна для людей тоді, коли захищає їні інтереси”), кожен п'ятий - з моделі беззаперечної цінності держави, третя за чисельністю група респондентів прагне ідентифікуватися заради впевненості і стабільності, i найменшою виявилася частка тих, хто вважає, що держава не може бути цінною. Показано, що самоідентифікування респондентів, які послуговуються різними метафоричними моделями, відповідає логіці засадничої метафори, що підтверджується результатами аналізу метафоричних смислів факторів. Встановлено, що переважна більшість метафоричних моделей громадянської та національної самоідентифікації молоді відповідає дискурсивному рівню, тобто метафоричні смисли обмежуються констатацією і не зумовлюють жодної активності. Концептуальні метафори вищого рівня (онтологічні), які структурують внутрішній світ і поведінку особистості, представлені в моделі епізодично і переважно зумовлюють національне самоідентифікування. Загалом рівень концептуалізації метафоричних практик національної самоідентифікації молоді вищий, ніж рівень практик громадянської самоідентифікації.

Ключові слова: метафори, моделі, комунікативні практики, громадянська та національна самоідентифікація.

\section{V. Zhadan}

\section{METAPHORICAL MODELS OF YOUTH CIVIC AND NATIONAL SELF-IDENTIFICATION}

It is substantiated the assumption that civic and national self-identification is stipulated by the metaphors chosen by the youth when characterizing different aspects of interaction with the state, the authorities, the society, etc. It is shown that typical metaphorical practices not only reflect the existing communication processes, but also actively influence their development. They play an important role not only in the construction of the world outlook of an individual, but also in the positioning regarding its separate systems, particularly the "individual - state", the "individual society" and the "individual - nation" systems. There are presented the findings of empirical investigation on metaphorical models of youth civic and national self- 
identification. The results of the factor analysis prove that students' self-identification is drown from the metaphor, which basic meaning is the value of the state. More than a half of the respondents construct their identity following the exchange model ("the state is valuable for its citizens when it protects their interests"). Every fifth respondent's identity is based on the model of the unconditional value of the state. The third biggest group of respondents strives for the sake of confidence and stability identification. The smallest group turned out to be the respondents who reject the value of the state. The self-identification of respondents following different metaphorical models corresponds to the logic of the key metaphor. This is proved by the results of analysis of metaphorical meanings of the following factors. The overwhelming majority of the metaphorical models of youth civic and national self-identification corresponds to the discursive level, i. e. metaphorical meanings are limited to connotation and do not stipulate any activity. The conception metaphors of the upper level (ontological ones), which structure the inner world and behavior of an individual, are sporadically represented in the model. They predominantly stipulate national self-identification. In general, the level of conceptualization of the metaphorical practices of youth national selfidentification is higher than the level of civic self-identification practices.

Key words: metaphors, models, communication practices, civic and national self-identification.

Постановка проблеми, аналіз останніх досліджень і публікацій. У пропонованому дослідженні семіотичний компонент комунікативних практик вивчався крізь призму метафоричних смислів комунікації, які, на нашу думку, опосередковують, репрезентують і конституюють громадянську і національну самоідентифікацію. Згідно 3 нашим припущенням, виявивши особливості впливу метафоричних практик на самоідентифікування студентської молоді, ми зможемо визначити напрями трансформування метафоричних моделей комунікації та активізувати процеси громадянської і національної самоідентифікації молоді.

Ідея семіотичного аналізу комунікативних процесів не нова ще Ф. де Соссюр вважав семіотику наукою психологічною і відносив до сфери іiі інтересів, з-поміж інших, інформаційні і соціальні процеси та особливості функціонування і розвитку культури.

Розрізняють “концептуальну метафору” i "метафоричну модель" як сукупність метафор певного метафоричного поля, що відображають загальну семантику картини світу комуніканта. Метафоричні моделі різної складності є свого роду схемами (у нашому випадку - практиками) сприймання, осмислення і поведінки людини [1].

Метафори здатні репрезентувати новий досвід, для якого ще бракує відповідного оформлення в понятійних концептах, і формувати теоретичні абстракції для опису об’єктів, які емпірично недоступні. Тобто процес метафоризації приводить до отримання нового знання про світ, яке, на думку П. Рікера, здатне змінити наше бачення світу, спосіб сприймання речей [2], відтак метафори виконують функцію когнітивних моделей аспектів реальності, які репрезентуються [3].

Метафора задає цілісне бачення предметної галузі, відображає взаємодію різних рівнів знання, організовує аргументативний дискурс, 
поєднуючи чуттєве і раціональне [4], а отже, застосування метафор у процесі комунікації спрощує розуміння, сприяє розширенню, поглибленню смислу [5]. Метафори структурують не лише мислення, а й дії та схеми самопроектування особистості [6], опосередковують той рівень суб'єктності, на якому особа визначається щодо власної свободи, відповідальності, сенсу життя тощо [7].

Як засіб пізнання, метафора відіграє важливу роль не лише в конструюванні картини світу особистості, а й у позиціюванні щодо окремих її систем, зокрема й таких, як “людина - держава”, “людина спільнота", “людина - нація". Метафоричні практики комунікації не просто відображають реальні комунікативні процеси, а й активно спрямовують їхній розвиток, оскільки самі стають невід'ємною і почасти імпліцитною частиною культури. А отже, метафоризацію можна вважати механізмом когнітивно-дискурсивного моделювання дійсності.

Окрім концептуалізації досвіду (“концептуальна система людини структурована і визначена за допомогою метафор” [8, с. 27]), до функцій метафори відносять також структурування дійсності, ідентифікацію, класифікацію. Апелюючи до уяви та інтуїції, вона має ще й потужний потенціал переконування і формування ставлень, відтак виконує експресивну, аргументативну, сугестивну та персуазивну функції [8-10].

Е. Лассан вирізняє три рівні існування політичних метафор: 1) рівень структурування практичної діяльності (метафора артикулюється в комунікативних практиках і регулює діяльність); 2) дискурсивний рівень концептуальної метафори (метафора використовується для акцентування схожості, але не тотожності, відтак не зумовлює відповідних практичних дій); 3) власне мовний рівень існування концептуальної метафори (метафоричні позначення реальності $є$ певними “кліше", що втратили емоційний потенціал) [11].

Дж. Лакофф і М. Джонсон виокремлюють: 1) структурні мета-

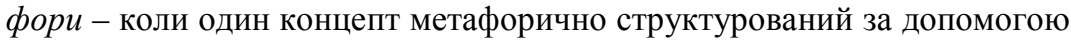
термінів іншого; 2) орієнтаційні метафори, які організують одну систему концептів щодо іншої, та 3) онтологічні метафори, які репрезентують способи трактування подій, дій, емоцій, ідей тощо як предметів і речей, створюють лексику внутрішнього світу особистості та ії емоцій [8].

Не вирішені раніше частини загальної проблеми. Попри значний інтерес науковців до метафоричних компонентів політичної свідомості і поведінки особливості впливу метафоричних концептів комунікативних практик на громадянську і національну самоідентифікацію особистості практично не вивчено.

У своєму дослідженні ми виходили 3 припущення, що аналіз метафоричних висловів, якщо їх співвіднести з метафоричними концептами, дасть змогу скласти уявлення про особливості національних та громадянських настановлень, цінностей і цілей молоді. На користь 
такого припущення свідчать результати численних емпіричних досліджень впливу частотних і семантичних параметрів метафор на політичні позиції комунікантів [12-14].

Дослідження метафоричних компонентів комунікативних практик передбачало кількісний (частота залучення метафор респондентами 3 різною громадянською і національною самоідентифікаціями), якісний (зміст метафор, на яких вибудовуються ті чи ті типи громадянської і національної ідентифікації), та системно-ієрархічний аналіз метафоричних конструктів як чинника громадянської і національної самоідентифікації.

Мета дослідження: виявити типові метафоричні моделі, які репрезентують комунікативний простір та зумовлюють громадянську і національну самоідентифікацію молоді.

Виклад основного матеріалу дослідження. В емпіричному дослідженні було використано авторський опитувальник, розроблений на основі раніше визначених показників громадянської і національної ідентифікації та іхніх виявів на різних рівнях самоідентифікування. Конструюючи опитувальник, ми виходили 3 того, що кожен із показників може бути репрезентований метафоричними практиками, які відповідають різним рівням самоідентифікації та утворюють континуум, на одному полюсі якого - метафори-кліше, а на протилежному - метафори-регулятори практичної діяльності.

До показників громадянської самоідентифікації було віднесено: суб'єктність життєвої позиції, прийняття громадянської відповідальності, потребу у свободі, залучення до громадянської взаємодії, часову орієнтацію, дистанційованість влади, інтегрованість у проблеми спільноти, сенс громадянства, форми вияву громадянськості; до показників національної - переживання належності до нації, бачення перспектив розвитку держави, уявлення про цінність держави для людей, національний міф, уявлення про політичну націю, самопроекцію в майбутнє, цінності і проблеми держави, геополітичне спрямування, ставлення до історії. У кожному з 18 запитань респонденти мали обрати з чотирьох альтернатив той метафоричний вислів, який найбільшою мірою відповідає їхньому світобаченню і визначає їхню поведінку. Щоб обмежити спектр інтерпретацій пропонованих метафор, у кожній з альтернатив поряд 3 метафоричним конструктом (у дужках) пропонувався варіант її конкретизації (наприклад, 3-поміж метафоричних оцінок свого життя пропонувався варіант “пливу за течією” (живу як виходить).

У дослідженні взяли участь 216 студентів закладів вищої освіти iз чотирьох регіонів країни: Центрального (м. Дніпро), Східного (м. Харків), Західного (м. Львів) та Південного (м. Херсон).

Обробка отриманих результатів здійснювалася за допомогою відомих статистичних методів, у тому числі кореляційного та факторного аналізу. 
Розгляньмо відтак факторну модель метафоричних практик (табл.), що зумовлюють національну і громадянську самоідентифікацію студентської молоді (сумарна дисперсія - 51,6\%). Як видно з таблиці, переважна більшість метафоричних практик громадянської і національної самоідентифікації молоді відповідає дискурсивному рівню, тобто комунікативні практики обмежуються констатацією і не передбачають відповідних практичних дій.

Таблиия

Факторна модель метафоричних практик студентської молоді

\begin{tabular}{|c|c|c|c|c|}
\hline Фактори* & Показники & Метафоричні смисли & $\begin{array}{l}\text { Рівень } \\
\text { мета- } \\
\text { фори** }\end{array}$ & $\begin{array}{c}\text { Вид } \\
\text { мета- } \\
\text { фори } * * *\end{array}$ \\
\hline $\begin{array}{c}\mathrm{F} 1 \\
(16,8 \%)\end{array}$ & $\begin{array}{l}\text { Уявлення про цін- } \\
\text { ність держави }\end{array}$ & $\begin{array}{l}\text { Цінна лише тоді, коли захищає } \\
\text { інтереси. }\end{array}$ & 2 & $\mathrm{Op}$ \\
\hline $\begin{array}{c}\mathrm{F} 2 \\
(8,2 \%)\end{array}$ & $\begin{array}{l}\text { Дистанціювання } \\
\text { влади. } \\
\text { Потреба у свободі. } \\
\text { Проблеми держави. } \\
\text { Самопроекція в } \\
\text { майбутнє }\end{array}$ & $\begin{array}{l}\text { Влада справедлива і дбає про } \\
\text { людей. } \\
\text { Я вільний, і моя свобода понад } \\
\text { усе. } \\
\text { Боротьба за незалежність триває. } \\
\text { Не бачу можливості себе реалі- } \\
\text { зувати в цій країні }\end{array}$ & $\begin{array}{l}2 \\
2 \\
2 \\
2\end{array}$ & $\begin{array}{l}\text { Op } \\
\text { Op } \\
\text { Op } \\
\text { Op }\end{array}$ \\
\hline $\begin{array}{c}\text { F3 } \\
(7,2 \%)\end{array}$ & $\begin{array}{l}\text { Геополітичне спря- } \\
\text { мування. } \\
\text { Національний міф }\end{array}$ & $\begin{array}{l}\text { Національна незалежність і без- } \\
\text { пека держави. } \\
\text { Спочатку - сильна економіка, а } \\
\text { потім - місце у світі }\end{array}$ & $\begin{array}{l}1 \\
2\end{array}$ & $\begin{array}{l}\mathrm{OH} \\
\mathrm{OH}\end{array}$ \\
\hline $\begin{array}{c}\mathrm{F} 4 \\
(6,8 \%)\end{array}$ & $\begin{array}{l}\text { Інтегрованість до } \\
\text { політичної нації. } \\
\text { Практики грома- } \\
\text { дянської взаємодії. } \\
\text { Прийняття грома- } \\
\text { дянської відпові- } \\
\text { дальності } \\
\end{array}$ & $\begin{array}{l}\text { Знати історію - щоб не повто- } \\
\text { рювати помилок, а традиції у } \\
\text { кожного покоління свої. } \\
\text { Залежать від ситуації і проблеми. } \\
\text { Люди обирають владу і поді- } \\
\text { ляють відповідальність за країну }\end{array}$ & $\begin{array}{l}2 \\
2\end{array}$ & $\begin{array}{l}\text { Op } \\
\text { Op }\end{array}$ \\
\hline $\begin{array}{c}\text { F5 } \\
(6,5 \%)\end{array}$ & $\begin{array}{l}\text { Часова орієнтація } \\
\text { життя. } \\
\text { Громадянська } \\
\text { активність. } \\
\text { Життєва позиція. } \\
\text { Ставлення до } \\
\text { проблем держави }\end{array}$ & $\begin{array}{l}\text { Живу надіями на краще життя. } \\
\text { Долучаюсь до розв'язання проб- } \\
\text { лем, бо відповідаю за себе та ін- } \\
\text { ших. } \\
\text { Приймаю життя і змінюю його. } \\
\text { Немає однозначних смислів і } \\
\text { відповідей, треба розв’язувати } \\
\text { проблеми і йти далі }\end{array}$ & $\begin{array}{l}2 \\
1\end{array}$ & $\begin{array}{l}\text { Op } \\
\text { Op }\end{array}$ \\
\hline $\begin{array}{c}\text { F6 } \\
(6,1 \%)\end{array}$ & $\begin{array}{l}\text { Переживання нале- } \\
\text { жності до нації. } \\
\text { Форми вияву } \\
\text { громадянськості. } \\
\text { Сенс (цілі) } \\
\text { громадянства } \\
\end{array}$ & $\begin{array}{l}\text { Іноді пишаюсь своїм народом, } \\
\text { іноді соромно за українців } \\
\text { Дотримуватися традицій і } \\
\text { звичаїв. } \\
\text { Підвищення якості життя }\end{array}$ & $\begin{array}{l}2 \\
2 \\
2\end{array}$ & $\begin{array}{l}\text { Op } \\
\text { C } \\
\text { Op }\end{array}$ \\
\hline
\end{tabular}

Примітка: * - номер фактору та його внесок у сумарну дисперсію; ** - рівні метафор: 1 - структурування діяльності, 2 - дискурсивний, 3 - мовний; *** - види метафор: С структурна, Ор - орієнтаційна, Он - онтологічна. 
Концептуальні метафори вищого рівня (онтологічні), з яких “вибудовуються" сприймання та інтерпретації, що структурують внутрішній світ і поведінку особистості, представлені в моделі епізодично і переважно зумовлюють національне самоідентифікування (геополітика, державний міф, ставлення до проблем держави). При цьому метафоричне поле уявлень про спільноту, яка утворює українську політичну націю, узагалі не увійшло у факторну модель, що може свідчити як про фрагментарність, так і про суперечливість та дражливість смислів комунікативних практик, які зумовлюють самоідентифікацію молоді 3 політичною нацією.

Перші три фактори утворені переважно показниками метафоричних практик національної самоідентифікації, показники практик громадянської самоідентифікації переважають у четвертому і п’ятому факторах. До того ж внесок у сумарну дисперсію показників, що репрезентують практики національної самоідентифікації, істотно вищий, що дає підстави для висновку про те, що громадянська самоідентифікація є похідною, вторинною щодо національної.

Громадянське та національне самоідентифікування студентської молоді структурується уявленнями про цінність держави для людини перший фактор утворив саме цей показник національної самоідентифікації. Більше ніж половина респондентів (55,6 \%) вибудовують взаємодію 3 державою з метафори обміну: будуть ï цінувати і готові ідентифікуватися лише 3 державою, яка буде захищати їхні інтереси. Водночас кожен п'ятий респондент практикує метафору держави як беззаперечної цінності, за яку варто боротись.

Розгортання метафоричної моделі світу респондентів у наступних факторах відповідає логіці засадничої метафори: більшість із тих, чия ідентифікація вибудовується 3 метафори обміну, дистанціюються від влади й очікують, що вона буде справедливою і дбатиме про людей, не обмежуючи їх ні в чому (“моя свобода понад усе"). Перспективи нації молодь пов'язує з боротьбою за незалежність, водночас тут і зараз не бачить можливості для майбутньої самореалізації у власній країні. Респонденти визнають важливість національної незалежності та безпеки, при цьому пов'язують геополітичні перспективи держави з її економічною незалежністю; усвідомлюють важливість знання своєї історії і традицій для запобігання повторенню помилок; усвідомлюють зумовленість розвитку країни політичним вибором громадян. При цьому студентство живе надією на краще майбутнє, вибірково долучається до громадянських ініціатив, декларуючи готовність приймати життя таким, яке воно $\epsilon$, і змінювати себе й світ навколо себе. Молодь відмовляється заглиблюватись у національно-політичні проблеми держави, водночас сенс громадянськості вбачає у створенні громадянського суспільства, яке змінить життя на краще. 
Респонденти, які вибудовують ідентичність з метафори беззаперечної цінності держави, частіше оперують смислами, властивими вищим рівням суб' єктності. Це стосується насамперед вибору форм громадянської активності; усвідомлення того, що Україна ще не є незалежною державою, здатною захищати свої національні інтереси, і водночас переконаності в тому, що українці мають потенціал для творення сучасної політичної нації і захисту своєї державності; самопроекції в майбутнє своєї держави, готовності будувати їі відповідно до власних уявлень про те, якою вона має бути; переконаності в тому, що в сучасному світі не варто очікувати однозначних смислів і відповідей на питання, потрібно шукати способи розв'язання нагальних проблем і йти далі.

Відтак рівень самоідентифікування респондентів, які виходять 3 метафори обміну, на порядок нижчий за рівень громадянської і національної самоідентифікації тих, для кого держава $є$ беззаперечною цінністю.

Третя група респондентів узагалі не розуміє, навіщо держава потрібна людям і чим вона може бути цінною (таких у нашому дослідженні виявилося майже $6 \%$ ). Не орієнтовані на державу респонденти значно рідше приймають життя таким, яке воно $\epsilon$, і рідше готові брати відповідальність за себе і країну; частіше практикують епізодичне залучення до громадської діяльності; максимально дистанційовані від влади; переконані в тому, що ніхто не буде обстоювати їхні інтереси, а тому мало цікавляться життям і проблемами інших; вважають, що політикум лише декларує гарні наміри, але не дає відповідей на питання, які хвилюють людей; сприймають громадянство як формальну ознаку. Слід зазначити, що перелічені відмінності в метафоричних смислах цієї групи респондентів (крім ставлення до проблем українського державотворення) стосуються громадянського самоідентифікування.

Відчуття належності до політичної нації надає впевненості і стабільності 17 \% студентів. Респонденти, які вибудовують комунікацію 3 цієї метафори, значно рідше за решту опитаних приймають рішення щодо залучення до громадянської взаємодії залежно від конкретної ситуації та проблеми; частіше за інших очікують, що влада дбатиме про людей і буде справедливою; 3-поміж форм громадянської активності обирають участь у виборах усіх рівнів і дотримання прав інших; оптимістично налаштовані щодо перспектив української нації (вірять у те, що українці мають достатній потенціал для творення сучасної політичної нації і захисту своєї державності). Як і ті, хто переконаний у беззаперечній цінності держави, вважають, що не варто очікувати однозначних смислів і відповідей на питання, потрібно шукати способи розв'язання нагальних проблем і йти далі; що національна незалежність і безпека держави - це те, до чого варто прагнути.

Висновки. На основі узагальнення результатів дослідження та порівняльного аналізу особливостей метафоричних практик, що зумовлюють національну і громадянську самоідентифікацію молоді, з'ясовано: 
- рівень концептуалізації метафоричних практик національної самоідентифікації молоді вищий, ніж рівень практик громадянської самоідентифікації, що зумовлюється насамперед більшою визначеністю смислів національного в ідентифікаційному дискурсі;

- те, що у факторній моделі немає метафоричних конструктів, які репрезентують уявлення про українську політичну націю, свідчить про ототожнення молоддю національно-політичної i національноетнічної самоідентифікації;

- відмінності у виявлених метафоричних моделях самоідентифікації стосуються переважно метафоричного простору громадянської самоідентифікації молоді;

- 3 певною часткою умовності можна виокремити чотири типи метафоричних моделей громадянської і національної самоідентифікації студентської молоді.

Перший тип вибудовується з метафори обміну (самоідентифікація 3 державою, яка захищає інтереси); другий - з метафори беззаперечної иінності держави; третій тип виходить із метафори належності як запоруки впевненості і стабільності; четвертий - 3 метафори знецінення держави. Виділені типи співвідносяться з визначеними в теоретичній моделі рівнями громадянської та національної самоідентифікації.

Наступним етапом нашого дослідження буде визначення ресурсів та засобів трансформування комунікативних практик, які давали б змогу впливати на розвиток громадянської і національної самоідентифікації молоді. Можливості трансформування метафоричних практик зумовлені тим, що метафори радше символізують, аніж адекватно відображають реальність; це переважно гіпотетичні конструкти, які можуть бути підтверджені або заперечені [15]. Відтак, залучаючи в процесі комунікації відповідну аргументацію, у тому числі і метафоричну, соціальні актори можуть змінювати смисли ідентифікації, спрямовуючи процеси громадянського і національного самоідентифікування.

\section{Список використаних джерел}

1. Баранов, А. Н. (2004). Метафорические модели как дискурсивные практики. Известия АН. Серия литературы и языка, 63(1), 33-43.

2. Рикер, П. (1990). Метафорический процесс как познание, воображение и ощущение. В Теория метафоры (с. 416-434). Москва: Прогресс.

3. Маккормак, Э. (1990). Когнитивная теория метафоры. В Теория метафоры (с. 358-386). Москва: Прогресс.

4. Решетникова, О. В. (2010). Метафора в постнеклассическом познании. Взято из http://www.dissercat.com/content/metafora-v-postneklassicheskom-poznanii.

5. Зинченко, В. П. (2012). Живые метафоры смысла. В Зинченко В. П. (Ред), Методология психологии: проблемы и перспективы (с. 29-50). Москва; Санкт-Петербург: Центр гуманитарных инициатив.

6. Чепелєва, Н. В., Смульсон, М. Л., Зазимко, О. В., \& Гуцол, С. Ю. (2016). Самопроектування особистості у дискурсивному просторі. Київ: Педагогічна думка. 
7. Волкова, Д. Э., Орлов, А. Б., \& Орлова, Н. А. (2010). Знак, метафора, символ - методология субъектности. Психология, 7(3), 89-119.

8. Лакофф, Дж., \& Джонсон, М. Mетафоры, которыми мы живем. Москва: Едиториал УРСС.

9. Гуцол, С. Ю. (2007). Метафора як спосіб символічного вираження внутрішнього досвіду особистості. Філософія. Психологія. Педагогіка, 3(21), ч. 2, 109-116.

10. Ричардс, А. А. (1990). Философия риторики. В Теория метафоры (с. 44-67). Москва: Прогресс.

11. Лассан, Э. (2010). О формах существования концептуальних метафор как индикаторах силы и бессилия общества. Политическая лингвистика, 1(31), 24-33.

12. Анисимова, А. А. (2006). Роль метафоры в структуре политического дискурса. III Международнье Бодуэновские чтения: И. А. Бодуэн де Куртенэ и современные проблемы теоретического и прикладного языкознания, т. 1 (pp. 42-44).

13. Белт, Т. (2007). Газетные метафоры и политическое убеждение: экспериментальное исследование. Политическая лингвистика, 3(23), 10-19.

14. Саиф, А. (2014). Политическая метафора: когнитивный и прагматический аспекты. Филологические науки. Вопросы теории и практики, 10(40), ч. 3, 164-169.

15. Никитина, М. А. (2010). О когнитивном потенциале метафоры в научном тексте. Вестник Иркутского государственного лингвистического универcumema, 3(11), 157-161.

\section{References}

1. Baranov, A. N. (2004). Metaforicheskiye modeli kak diskursivnyye praktiki [Metaphorical models as discursive practices]. Izvestiya AN. Seriya literatury $i$ yazyka [News AS. Series of literature and language], 63(1), 33-43 (rus).

2. Riker, P. (1990). Metaforicheskiy protsess kak poznaniye, voobrazheniye i oshchushcheniye [Metaphorical process as cognition, imagination and feeling]. In Teoriya metafory [Theory of metaphor] (p. 416-434). Moscow: Progress Publ.

3. Makkormak, E. (1990). Kognitivnaya teoriya metafory [Cognitive theory of metaphor]. In Teoriya metafory [Theory of metaphor] (pp. 358-386). Moscow: Progress Publ.

4. Reshetnikova, O. V. (2010). Metafora v postneklassicheskom poznanii [A metaphor is in after nonclassical cognition]. Retrieved from http://www.dissercat.com/ content/metafora-v-postneklassicheskom-poznanii.

5. Zinchenko, V. P. (2012). Zhivyye metafory smysla [Living metaphors of sense]. In B. P. Zinchenko (Ed.), Metodologiya psikhologii: problemy i perspektivy [Methodology of psychology: problems and prospects] (pp. 29-50). Moscow; St. Petersburg (rus).

6. Chepeleva, N. V., Smulson, M. L., Zazimko, O. V., \& Gutsol, S.Yu. (2016). Samoproektuvanyia osobystosti u dyskursyvnomu prostori [Planning of itself of personality is in discursive space]. Kyiv: Pedahohichna dumka Publ. (ukr).

7. Volkova, D. E., Orlov, A. B., \& Orlova, N. A. (2010). Znak, metafora, simvol metodologiya subyektnosti [A sign, metaphor, symbol, is methodology of subject]. Psikhologiya [Psychology], 7(3), 89-119 (rus). 
8. Lakoff, G., \& Johnsen, M. (2004). Metafory, kotorymi my zhivem [Metafors We live by]. Moscow: Editorial URSS Publ. (rus).

9. Hutsol, S. Yu. (2007). Metafora yak sposib symvolichnoho vyrazhennia vnutrishnoho dosvidu osobystosti [Metaphor as method of symbolic expression of internal experience of personality]. Filosofiia. Psykholohiia. Pedahohika [Philosophy. Psychology. Pedagogics], 21(3), part 2, pp. 109-116 (ukr).

10. Richards, A. A. (1990). Filosofiya ritoriki [Philosophy of rhetoric] In Teoriya metafory [Theory of metaphor] (pp. 44-67). Moscow: Progress Publ. (rus).

11. Lassan, E. (2010). O formakh sushchestvovaniya kontseptualnykh metafor kak indikatorakh sily i bessiliya obshchestva [About the forms of existence of conceptual metaphors as indicators of force and weakness of society]. Politicheskaya lingvistika [Political linguistics], 1(31), 24-33 (rus).

12. Anisimova, A. A. (2006). Rol metafory v strukture politicheskogo diskursa [A role of metaphor is in the structure of political discourse]. III Mezhdunarodnyye Boduenovskiye chteniya [III the International Boduen's reading], Vol. 1, pp. 42-44 (rus).

13. Belt, T. (2007). Gazetnyye metafory i politicheskoye ubezhdeniye: eksperimentalnoye issledovaniye [Newspaper metaphors and political persuasion : experimental researc]. Politicheskaya lingvistika [Political linguistics], 3 (23),10-13 (rus).

14. Saif, A. (2014). Politicheskaya metafora: kognitivnyy i pragmaticheskiy aspekty [Political metaphor: cognitive and pragmatic aspects]. Filologicheskiye nauki. Voprosy teorii i praktiki [Philological sciences. Questions of theory and practice], 10(40), Part. 3, pp. 164-169 (rus).

15. Nikitina, M. A. (2010). O kognitivnom potentsiale metafory v nauchnom tekste [About cognitive potential of metaphor in scientific text]. Vestnik Irkutskogo gosudarstvennogo lingvisticheskogo universiteta [Announcer of Irkutsk State Linguistic University], 3(11), 157-161 (rus).

(C) Жадан I. B. 